\title{
Logic Model Evaluation For SMK / SMA Teachers in Dual Expertise Educational Certification Program
}

\author{
$1^{\text {st }}$ Ali Basyah \\ Pendidikan Kejuruan \\ State University of Malang \\ alibasyah.mm@gmail.com
}

\author{
$2^{\text {nd }}$ Eddy Sutadji \\ Pendidikan Kejuruan \\ State University of Malang \\ eddy.sutadji.ft@um.ac.id
}

\begin{abstract}
Aims to develop a framework for evaluation and monitoring of Dual Expertise Education Certification Program for SMK / SMA Teachers conducted by the Indonesian Ministry of Education and Culture through PPPPTK BOE Malang. Helping observers assess the content and advantages of the program. With a primary focus on teacher performance program participants who engage in activities after through validation of key stakeholders. The framework of the evaluation method includes five main logic model structures: resources / inputs, activities, outputs, outcomes and impacts. The method used is document analysis and interview with reference of previous Teacher Learning Program. Researchers identified aspects of the study based on the five main structures. The data is collected gradually from the development stage of the Teacher Learning Program, during the on-in1, on-in2 system activities, to the prediction of implementation of the field results. The results have an impact on increasing the score of teachers' UKG scores and improving student learning.
\end{abstract}

Keyword-dual expertise program, logic model evaluation, smk

\section{BACKGROUND}

One of the strategic ways of revitalization of SMK conducted by the Government of Indonesia in the short term is a recertification program of expertise and recertification of educators for 15000 teachers of SMK / SMA. Hereinafter referred to as Dual Expertise Program. It is expected that the number of productive teachers of SMK in Indonesia can be fulfilled [1]. Teachers involved are teachers affected by the implementation of the Curriculum 2013. Impacts such as the loss of subjects, reduced number of hours of study and uneven distribution of teachers within a particular area.

The design of the Dual Expertise Program implementation from the teacher engagement side will perform activities such as: a) self-directed guided learning in vocational schools or on other SMK On-Service Training, b) Training and Education (In-Service Training), c) Apprenticeship in the business and industry (DU / DI); and d) certification of expertise by Professional Certification Institution (PCI) and recertification of teachers in positions through Pendidikan dan Latihan Profesi Guru (PLPG). Design using a sandwich system On-In-On-In service training [1]. Executor of the program is Pusat Pengembangan Pemberdayaan Pendidik dan Tenaga
Kependidikan Bidang Otomotif Elektronika (PPPPTK BOE) Malang.

To improve outcomes that meet the needs of the department, it requires mechanisms to monitor and evaluate impacts on training outcomes. Developing a logic model evaluation is an important first step in program evaluation [9]. As a pragmatic tool carrying out the review, strengthening the quality of reviews, communication tools dissemination findings [3]. Aim to provide street map stakeholders describing the sequence of related events that link the needs of the planned program to the desired outcomes of the program. Mapping a proposed program helps visualize and understand how human and financial investments can contribute to achieving desired program objectives and can lead to program improvement [13] [14]. The process used in producing the logic model evaluation helps the program to: a) establish a clear mission with an understanding of what is invested (input); b) describe what the program will do, who will participate, and what environmental factors can be played out (output), and c) determine outcomes at three levels (short, medium and long term) to measure success or failure [5].

Basically in Dual Expertise Programs, logic model evaluation is a systematic and visual way to present and share an understanding of the relationships between the resources they have to operate the program, the activities to be performed, and the changes or outcomes to be achieved. The most basic of logic model evaluation is a description of how convincing the program will work. It uses words and pictures to visualize the sequence of activities that are considered to bring change and how these activities are related to the expected outcomes of this program. Arranged in a columned format with text in a box and linked with a one-way arrow [12].

Benefits of using the Logic Model Evaluation include: a) Program design, as part of the evaluation so as to stay focused on outcomes, both temporary and long-term. b) Have a strong base for continuous evaluation. Can decide more systematic which part of the program to be studied, whether the assumption is correct or not. c) There is value in the process of developing the logic model. The model itself provides vocal points for discussion or explanation to others, creating a sense of ownership among stakeholders [13] [14]. The basic components of the logic model evaluation are 
shown in Figure 1 below. This component describes the relationship between the planned work and the expected results. Described numerically with steps 1 through 5 .

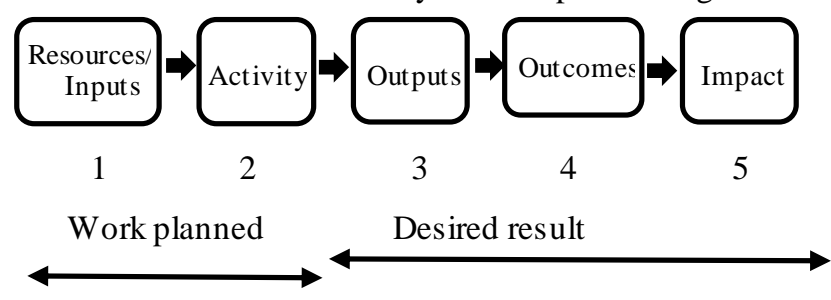

Fig. 1. Basic Logic Model Evaluation Components

Elements of logic model evaluation are defined as: a) Resources are also sometimes called Inputs can be human, financial, organizational, community, or system in any combination; b) Activity is the specific action that shapes the program reflecting the tools, processes, events, and other intentional tools in the program; c) Outputs are specific activities to be produced or created including description of the type, level, and audience or targets submitted by the program; d) Outcomes are about change, often in program participants or organizations, as a result of the program including certain changes in awareness, knowledge, skills, and behavior, and e) Impact is a major goal change in organizations, communities, or other systems that bring about time implications [4].

In sequence it can be explained that: a) Specific resources are required to run Dual Expertise Program, b) If you have access to resources, you can use them to complete the planned activities of the program, c) If you have completed the activity plan, products and services desired, d) If you have completed planned activities to the extent desired, then the program participants will benefit in certain ways, e) If the benefits for program participants are achieved, certain changes in the organization, community, or system may be expected happen.

The effective evaluation and success of an effective Dual Expertise Program depends on the clear assumptions and expectations of stakeholders on how and why the program will solve the problem of productive teacher shortages, generate new possibilities of dual skill in teachers, and utilize most valuable assets of teachers who lack the hours Teaching and / or subjects lost as a result of the implementation of the Indonesian Curriculum 2013. The logical modeling approach helps create a shared understanding and focus on program objectives and methodology, linking activities with projected results.

\section{AIM}

This study aims to construct the components of resources / inputs, activities, outputs, outcomes, and impacts on the Dual Expertise Education Certification Program for SMK / SMA teachers organized by the Ministry of Education and Culture through PPPTK BOE Malang 2017 (http://www.vedcmalang.com).

\section{METHOD}

This study uses document analysis and interviews with reference to the implementation of previous learner teacher programs (https://gurupembelajar.id). By reviewing the literature that can be used as a guide for researchers. The qualitative research method of document study was conducted on several inter-evaluation reports, educational and training processes, journals that have been referred to as literature review, and analyzed with data collected using Constant Comparative Method (CCM) linking, coding and analyzing data [17]. This technique is used because this is a regular method. Review and evaluate paper documents and electronic resources.

Source of data derived from the results: a) Fucus Group Discussion (FGD) Dual Expertise Skills in WhatApps; b) Structured Interviews Online (WTOl) through Google Form; c) Field observation. Informant data in this study as in the following table:

T ABLE 1. DETAIL OF INFORMANT OF RESEARCH

\begin{tabular}{|l|l|c|c|}
\hline No. & \multicolumn{1}{|c|}{ Source of Informant } & FGF & WTOI \\
\hline 1. & National Instructor & 5 & \\
2. & Dual Expertise Teacher & & 15 \\
3. & Program Operator & & 5 \\
\hline
\end{tabular}

Ethically because it involves the human element in this study, all informants freely agree to fill the instrument and discuss, to get basic information [11].

The program operator is limited to technical implementation unit under the Directorate General of GTK, Kembdikbud that is: a) PPPPTK BOE Malang; b) Provincial Education Department in providing teacher data which will follow Dual Expertise Program, including data verification; c) Business and Industry in the provision of a place for teachers to know the industry; d) Training institutions as a place to train vocational skills competencies for teachers of Dual Expertise Program which in this case is located in the school as a Learning Center.

\section{ANALYSIS AND RESULTS}

\section{A. The planned work/Situation Statement}

The first step in developing a logic model is to identify the problem of the productive shortage of teachers who are handled by the Dual Expertise Program and make the appropriate situation statement. In this logic model, a roadmap will be developed to overcome the lack of productive teachers in SMK, while on the other hand there are certain adaptive, normative, and productive teachers in SMK / SMA.

So as situation statement is:

In accordance with conditions 2016 from the Vocational Data SMK that there is a total lack of state and private productive teachers 91.861. In the short-term plan in 2017 implemented Dual Expertise Educator Certification Program as many as 15,000 teachers. 


\section{B. Desired results/Asumptions}

At this stage have identified several root causes and have found a way that has proven to have been successfully programmed earlier. A successful program for Dual Expertise Education Certification is a Teacher Learning Program as a follow-up to Teacher's Competence Test results held in 2015.

So as Assumtion is: a) Achieved Dual Teacher Educator Certification as many as 15000 teachers; Measurement of Success through Teacher's Competency Test and get new Education Certificate.

\section{Inputs}

Resources that can be included in the program to be successful. It can be the materials, people and resources you need to make the program work. List of resources in Dual Expertise Program such as: a) Study of Director General of Teacher and Education Personnel; b) PPPPTK BOE Malang; c) $101 \mathrm{SMKs}$ Learning Center; d) 1.227 SMK / SMA teachers target; e) National Instructor; f) Learning Teacher Curriculum; g) Business and Industry (DUDI) and Professional Certification Institution (PCI); h) Management Information System Training and Education; i) Educational Institute of Education Personnel (LPTK); and j) Financial

\section{Activity}

The activities undertaken starting from: a) Program Development Planning conducted by the Director General GTK, Kemdikbud; b) Instructor Training conducted at PPPTK BOE Malang; c) Target Teacher Training at each Learning Center; d) Teacher Apprenticeship in Designated Schools; e) Certification of Expertise to be performed by Professional Certification Institution (PCI), and Educator Certification conducted by LPTK.

\section{E. Outputs}

Outputs of the activities undertaken are: a) Technical Instruction 1 (IN-1) and In Service Training 2 (IN-2) Dual Expertise Education Certification Program for SMK / SMA Teachers; b) National Instructor who will teach target teachers at the Learning Center; c) Dual Expertise Skills results of training activities; d) Certified Expertise Teacher from Professional Certification Institution; e) Teacher Certified Educator from LPTK.

\section{F. Outcomes}

There are three runs against specific changes in the behavior, knowledge, skills, beliefs or attitudes of program participants. The short-term important things that want to be changed in the target population as a result of the program is the improvement of knowledge, especially in the reading content of each skill. The medium term is expected to have an alternative learning strategy with science that has been certified skillfully from PCI, and the long term has the belief of its scientific ability so that it can have multiple learning strategies with double expertise possessed and professionally certified by LPTK.

\section{G. Impact}

Impact is the long-term change to be achieved in the target teacher target population. This may include changes to the individual ability of the target teacher in improving the score on the implementation of the Teacher Competency Test (UKG), and / or impacting on improving student learning.

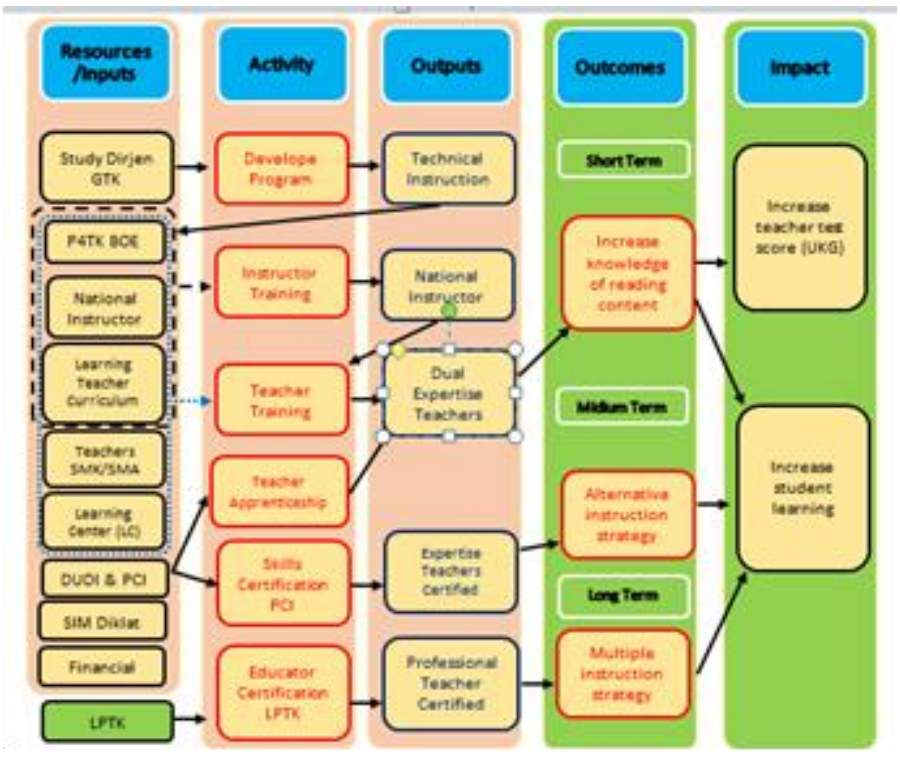

Fig. 2. Logic Model for Dual Expertise Education Certification Program

\section{V.DISCUSSION}

By using the Dual Expertise Program as a conceptual application of logic model evaluation, the researcher attempts to show that the use of concept mapping procedures in developing component constructions is to articulate those changes. In particular the construction is done to identify the course of the target population in receiving the program, its position in the program structure, as well as the programming strategies and the expected mental impact models of the program.

There are two major groups namely the process side and the output side. The process side includes the components of resources / inputs, activity and outputs. While the output side includes component outcomes and impact. Complete construction of components and indicators of the Dual Expertise Education Certification Program for SMK / SMA teachers is presented in Figure 2.

Constructing the logic model component to form a concept map is a concept for organizing complex ideas about the implementation of the Dual Expertise Program and describing how a program works. Concept mapping helps reveal the fundamental assumptions that guide service delivery and therefore help articulate the theory of change.

Each activity through evaluation stage. Just as product development programs are evaluated. Instructor training, teacher training in learning centers, teacher apprenticeship activities, certification by Professional Certification 
Institution (PCI) and final Educator Certification by LPTK also through evaluation stage.

\section{CONCLUSION}

Constructing components of inputs, activities, outputs, outcomes and impacts on Dual Expertise Programs by developing appropriate and measurable indicators during the planning phase is key to good evaluation. Early identification of indicators allows stake holders, program managers, and teams to know the baseline data that may be available to help evaluate the program.

The logic model is useful for identifying program elements most likely to generate useful evaluation data, and to identify appropriate sequences for collecting data and measuring progress. Can be concluded that : [1]. The Logic Model helps explain how and why the program works; [2]. Logic Model can be used as a tool to improve planning, implementation and dissemination of Dual Expertise Education Certification Program for SMK / SMA Teachers; and [3]. Logic Models can help connect the need for a planned program to the desired outcome of the program.

The outcome indicators for measuring training should be based on the specific objectives described as part of the curriculum. Indicators for measuring behavior change should determine which behavior the program targets. Conditional indicators may require significant time investment to link medium-term outcomes with expected long-term outcomes through the implementation of targeted programs.

\section{REFERENCE}

[1] Dirjen GT K, Program Sertifikasi Pendidik Dan Sertifikasi Keahlian Bagi Guru SMK/SMA (Keahlian Ganda), Petunjuk Teknis Pelaksanaan In Service Training 1 (In-1) Dan In Service Training 2 (In-2), Kementerian Pendidikan dan Kebudayaan, Jakarta, 2017.

[2] E.T. Powell, L. Jones, and E. Henert, Enhancing Program Performance with Logic Models, University of Wisconsin-Extension, 2003.

[3] Kneale, Thomas \& Harris, Developing and Optimising the Use of Logic Models in Systematic Reviews: Exploring Practice and Good Practice in the Use of Programme Theory in Reviews, PLOS ONE DOI:10.1371/journal.pone.0142187 November 17, 2015.

[4] L. Knowlton \& C. Phillips, The Logic Model Guidebook, Better Strategies for Great Results, Second Edition. Sage Publications. Retrieved, 2013.

[5] L.L. Openshaw, A. Lewellen, and C. Harr, A Logic Model for Program Planning and Evaluation Applied to a Rural Social Work Department, Contemporary Rural Social Work, Vol. 3. ISSN: 2165 4611 Texas A\&M University-Commerce, 2011.

[6] Logic Model Workbook Innovation Network, Inc. $1625 \mathrm{~K}$ Street, NW, Suite 1050 Washington, DC 20006 (202) 728-0727 info@innonet.org www.innonet.org

[7] M.K. Sharon, Grounded Theory and the Constant Comparative Method: Valid Research Strategies for Educators, Journal of Emerging Trends in Educational Research and Policy Studies (JETERAPS) 3 (1): 83-86, 2012.

[8] Pusat Pengembangan Pemberdayaan Pendidik dan Tenaga Kependidikan Bidang Ot omotif Elektronika (PPPPTK BOE) Malang, www.vedc.malang, 2017.
[9] R. Renger, \& A, Titcomb, A Three-Step Approach to Teaching Logic Models, American Journal of Evaluation, Vol. 23, No. 4, 2002, pp. 493-503. ISSN: 1098-2140, 2002.

[10] S. Yampolskaya, M.N. Teresa, H. Mario and D. Koch, Using Concept Mapping to Develop a Logic Model and Articulate a Program Theory: A Case Example, American Journal of Evaluation, Vol. 25, No. 2, 2004, pp. 191-207 ISSN: 1098-2140, 2004.

[11] S.M. Damasceno, G. Abbad \& P.P. Meneses, Logic Models and Organizational Training Evaluations, Paidéia, 22(52), ISSN:217-227. doi:10.1590/S0103-863X2012000200008, 2012.

[12] W. Trochim, \& D. Cabrera, The complexity of concept mapping, Emergence: Complexity and Organization, 7, 11-22, 2005.

[13] W.K. Kellogg Fondation, Evaluation Handbook, One East Michigan Avenue East Battle Creek, Michigan 49017-4012 www.wkkf.org, 2004.

[14] W.K. Kellogg Fondation, Logic Model Development Guide, One East Michigan Avenue East Battle Creek, Michigan 49017-4012 www.wkkf.org, 2004. 